\title{
Strengthen the Method of Reforming Physical Education Curriculum in Junior Middle schools
}

\author{
Wenchao Li \\ Capital University of Physical Education and Sports, Beijing, China, 100191
}

Keywords: PE in junior middle schools; teaching; reform method

\begin{abstract}
Physical education (PE) curriculum is not only the main form of PE in schools, but also a compulsory course in the teaching plan of China. In the PE curriculum, students can learn skills required in the syllabus, strengthen their physique, and be imbued with correct ideological and moral ideas. At present, the traditional teaching method cannot better meet the requirements of PE teaching, and it is necessary to strengthen the PE teaching curriculum in junior middle schools and adhere to the teaching guiding ideology of "health first". Therefore, it is very important to well arrange the PE curriculum, constantly strengthen reform of the teaching contents of PE curriculum, and it is also the development goal of PE education in schools at present.

With the rapid development and progress of the society, traditional teaching methods cannot well adapt to the current social needs, as the disadvantages thereof are gradually highlighted. PE in schools is the foundation of national sports, can improve the overall physical quality of citizens, and plays an important role in people's psychological and physical health. Teaching reforms should be constantly strengthened. PE teachers should seriously look on the reforms, attach importance to innovative learning, and constantly update the teaching methods to form good classroom teaching effects, which is also the main problem that needs to be solved by new teachers in the future, so as to constantly improve the current teaching level.
\end{abstract}

\section{Teaching centered on students' development}

$\mathrm{PE}$ and health curricula should run through the whole process from curriculum design to evaluation with students' needs and emotional states as key attentions. It is necessary to attach great importance to stimulating students' initiative, and promoting their progress and development in an all-round way. In order to give full play to students' subject status in class, teachers need to correctly guide students. Allowing students to learn according to their interests, and learn to any extent at will is a performance of giving up educational functions, and is also very undesirable. Therefore, in classroom teaching, teachers should do the following important work:

In class, teachers shall be able to create suitable scenarios, set problems of different difficulties, stimulate students' learning interests and thinking ability, guide students to produce strong thirst for knowledge, and form an equal and comfortable relationship between teachers and students, so that students can actively finish various learning tasks, discover questions therefrom, and strive to explore and discover questions. Teachers shall encourage students to communicate with each other and to dare to disclose their own views in class, fully respect each student, appreciatively look on all sorts of questions proposed by students, try not to deny students, never hit students' self-confidence, correctly guide students' thinking, praise valuable questions put forward by students, correctly guide students to get answers through their own thinking and cooperation, and strengthen communication between students and teachers, so that students continuously improve and perfect their ability in interaction, and sublimate their emotional attitudes and values. In class, teachers should properly change their roles from leaders and directors to partners, guiders and facilitators in teaching, and can establish friendly relationships with students. Furthermore, teachers should also constantly improve students' independent learning and exercise ability, so that students can actively do physical exercises. Teachers should create various opportunities for students to give play to their abilities and to cultivate their creativity and competitiveness, so as to be able to better 
meet various challenges. In classroom teaching, it is necessary to fully reflect the democratic teaching spirit, and allow students to evaluate the whole process of teaching and learning in a certain way. At present, teachers shall be able to make full use of information technology conditions, guide students to correctly collect all kinds of information and learning resources, so that students can make full use of the information technology, which becomes a learning tool, and provides students with more help.

\section{Formulate, and clearly and concretely express specific teaching objectives}

Teaching objective plays a certain role in guiding and motivating teaching jobs, is the main purpose at the beginning of one lesson, needs to be completed in the teaching process, is also the end result of the lesson, and facilitates evaluation of the effect of each lesson based on the achievement of the teaching objective. Therefore, teaching objectives should be associated with the actual situation of students, be clearly and specifically expressed in clear levels, and be formulated in moderate difficulty after fully considering students' physical and mental development, so that students of different levels can meet the requirements after making certain efforts.

Teaching objectives of the PE curriculum include sports skills, related theoretical knowledge of sports skills, physical health, social adaptability, etc. The content of each lesson should aim to achieve objectives in one or two aspects thereof, but does not need to relate to every aspect. Otherwise, it will be difficult to achieve good effects.

\section{Pay attention to individual differences among students}

Different students have different physical qualities, different receptivities, and different psychological and personality traits. Therefore, PE teachers should teach students through teaching activities in different levels according to students' aptitude, do a good job in guiding classification, and meet students' needs for development to the greatest extent, so that students can fully experience the joy of learning and success.

For example, in leap-type high jump teaching, students may be divided into different levels based on their mastery degrees since the second class. The students who do not fully master the content may continue to exercise using low rubber band, the students of medium level may increase the difficulty of exercise by enhancing the height of the rubber band, while some students of better ability may exercise using a cross bar, can understand the rules of high jump, such as venue, equipment, score measure method and the like, shall also be encouraged to help other students to exercise.

\section{Master the learning motivations of students in junior middle schools, stimulate their interests in class participation, and constantly develop related resources based on their situations}

1) Firstly, teachers shall understand students' learning objectives and stimulate students' learning motivations. Student motivation is the key to achieving objectives. Therefore, teachers shall teach students to correctly understand and know about the learning objectives of PE and related health curricula, so as to facilitate teachers to better meet the requirements of the teaching objectives. After understanding the contents to be learned in the PE curriculum of junior middle schools, students shall know about why to learn these things, and what effects to be finally achieved. Only by knowing about the benefits and values thereof, can students look on every task in positive attitudes.

2) Teachers shall properly stimulate students' learning interests. Many educationalists have said that interest is a very good teacher. As can be found through comprehensive analysis on the learning characteristics of students in junior middle schools, interest is an important impetus for students' progress, and determines student's learning effects to a great extent. In the process of PE teaching in junior middle schools, teachers shall stimulate students' learning interests in a variety of ways, so that students produce strong thirst for knowledge, and constantly improve their PE quality level. 
Moreover, students in junior middle schools are in adolescence, implying that it is difficult for them to maintain great interests. Therefore, after stimulating students' interests, teachers shall also allow, by a variety of means, students to keep enthusiasm for learning and to constantly consolidate learned contents, and guide students to establish competitive consciousness, so that students exert their physical strengths, mental strengths, perseverance, etc. in sports games, defeat competitors, constantly challenge themselves, and feel the joy of success.

3) Requested by the new curriculum standard, the choice of teaching material resources is more open, different schools can develop teaching resources suitable for their own development after comprehensively considering local characteristics and actual situations of schools. Some folk physical exercises may also be added to classroom teaching. Schools shall develop students' imagination ability to the utmost, encourage students to take part in more discussions and creations, and give play to the subject status of students in class. Students shall also pay great attention to learning the teaching material contents, and cannot make no efforts to learn the teaching material contents because of the baldness thereof. Teachers give up some sport items because of being afraid of hurting students, firmly remember the main functions of school physical education in strengthening the PE teaching reform in junior middle schools, and cannot take PE curriculum as a curriculum for leisure and entertainment.

\section{Give full play to the incentive functions of evaluation}

Teaching evaluation can better reflect the combination effect of "leading role" and "subject status". Most schools in China only pay attention to the teaching results, while the teaching process is only a compulsory process, thereby greatly restricting the development of students' subjectivity. Therefore, it is necessary to not only attach importance to evaluation of the results, but also attach improved importance to evaluation of student learning process, pay attention to students' progress, cultivate students' emotional attitudes, values, etc. in teaching, and scientifically evaluate teaching in time, so that students can give full play to their own personality traits.

There are a lot of evaluation methods, including oral evaluation, gesture, facial expression, etc., and the evaluation plays a role in stimulating students, so that students will appreciate the evaluation and be encouraged. Therefore, it is necessary to promptly praise student's good performance, and properly criticize improper conducts, so as to better reflect the contents of the curriculum reform. Teachers' encouraging wording, affirmative gesture and the like will all bring sense of pride to students' psychology, and improve students' self-confidences, so that students complete classroom learning in best possible states. At the same time, different evaluation criteria should be set for different students to reflect evaluation of different levels and encourage students to make bold imaginations, so that students can better show their own personality traits.

\section{Strengthen curriculum reform of junior middle schools by flexibly using new curriculum standards}

Junior middle schools shall update their teaching ideas, teaching methods and so on, adhere to the diversity of teaching methods, constantly attempt to use a variety of new methods, and improve the disadvantages of traditional teaching. Teachers may choose the teaching contents, such as those items beneficial to students' physical and psychological health, and may also allow students to independently choose associated items, and give students enough space to choose schools.

\section{Conclusion}

In conclusion, in PE teaching, it is also necessary to give full play to teachers' leading role and students' subject status, and form classrooms in which teachers and students jointly participate. PE teachers shall explain health care knowledge, sports skills, etc., and improve students' physical quality, so that students form good athletic ability, and participate in various PE curriculum contents in order. Moreover, PE teachers should also constantly improve their own ability, and adhere to the 
path of lifelong learning.

\section{Acknowledgment}

Subject No: National Social Science Fund Educational Education Youth Project + "up-and-down", the first line of urban high school sports development and countermeasures research + CLA 130196

\section{References}

[1] Li Tianmei. Analysis and suggestion on the "second classroom" of PE teaching in junior middle schools- "active PE curriculum" [J]. New Curriculum: Middle School, 2012 (4).

[2] Liu Fengbiao. PE Teaching in Junior Middle Schools in the Context of New PE Curriculum [J]. Education, 2016 (6): 00169-00169. 